\title{
PENGARUH KUALITAS PRODUK DAN CITRA MEREK TERHADAP LOYALITAS KONSUMEN PADA PRODUK OLI FEDERAL DI WILAYAH JAKARTA TIMUR (STUDI KASUS PADA BENGKEL RESMI AHASS 2657 DEWI SARTIKA)
}

\author{
Agung Kresnamurti R.P.* \\ Ariani Putri*
}

\begin{abstract}
The purpose of this study are: 1)Knowing the description of the product quality, brand image, and consumer loyalty of Federal Oil, 2) Knowing the influence of product quality to consumer loyalty of Federal Oil, 3) Knowing the influence of brand image to consumer loyalty of Federal Oil, 4)Knowing the influence product quality and brand image simultaneously to consumer loyalty of Federal Oil. The unit of observation is 204 respondents who turn of motor oil in Dewi Sartika and use Federal oil consumption four times or more. Research designs used are descriptive and causal. Sample determination technique using convenience sampling. Data collection techniques using a questionnaire with a Likert scale from 1 to 5. The result of this descriptive study is variable of quality product significantly affects consumer loyalty of Federal Oil, variable of brand image significantly affects consumer loyalty of Federal Oil. Results of hypothesis testing through $t$ test and $F$ test shows the influence variable quality of product to the consumer loyalty, the effect of brand image variable to the consumer loyalty. From these studies show that the percentage contribution to the influence of quality of product and brand image to the consumer loyalty by $54.2 \%\left(R^{2}\right)$. The remaining $45.8 \%$ is influenced or explained by other variables not included in this research model.
\end{abstract}

Keywords: Quality of Product, Brand Image, Consumer Loyalty, Federal Oill

\section{PENDAHULUAN}

Supaya perusahaan dapat tumbuh dan berkembang dengan baik, maka perusahaan harus dapat mengantisipasi perkembangan ekonomi yang semakin kompetitif dengan melakukan strategi yang tepat agar tidak tersisih dalam persaingan. Hal itu dilakukan untuk mempertahankan kelangsungan hidup dan kemajuan perusahaan.

\footnotetext{
* Agung Kresnamurti R.P.\& Ariani Putri. Dosen Fakultas Ekonomi Universitas Negeri Jakarta
}

Perusahaan yang dapat bersaing dalam pasar adalah perusahaan yang dapat menyediakan produk yang berkualitas. Pada dasarnya konsumen tidak akan merasa puas dalam pemenuhan kebutuhan maupun keinginannya. Kualitas produk yang baik akan membuat konsumen merasa puas dalam pemakaian suatu barang. Tuntutan konsumen terhadap suatu produk, baik bentuk barang maupun jasa yang ditawarkan perusahaan semakin hari semakin 
meningkat. Konsumen akan mengharapkan produk yang dibelinya merupakan produk yang mempunyai kualitas yang baik.

Pada dasarnya kualitas produk menggambarkan sejauh mana kemampuan suatu produk untuk menampilkan kemampuannya atau melaksanakan fungsi-fungsi yang dimilikinya. Konsumen akan merasa puas jika produk yang dibelinya mampu memberikan kinerja atau dapat melebihi apa yang diharapkannya. Bila konsumen merasa puas terhadap produk yang di konsumsi, maka akan cenderung timbul suatu keinginan untuk membelikan pembelian secara teratur atau terus-menerus. Keinginan untuk melakukan pembelian ulang merupakan sikap yang paling menentukan konsumen agar terciptanya suatu loyalitas terhadap produk tersebut.

Dalam memilih suatu produk, yang dipertimbangan oleh konsumen selain kualitasnya, yaitu citra merek (brand image). Perusahaan harus menciptakan merek yang kuat, agar konsumen dapat membedakan antara produk perusahaan dengan produk perusahaan pesaingnya. Suatu merek harus menjadi suatu simbol yang cocok dan juga unik untuk mempresentasikan produk perusahaan tersebut dimata konsumen. Ini disebabkan karena hal pertama yang dilihat oleh calon konsumen dalam menetapkan pilihan adalah merek dari suatu produk.

Pengaruh kualitas produk dan citra merek terhadap loyalitas juga berlaku pada PT. Federal Karyatama. Perusahaan ini bergerak dalam bidang produksi oli. Salah satu merek andalannya adalah Oli Federal. Merek ini bersaing dengan pesaing utamanya yaitu TOP 1 . Dapat dilihat dari segi harga yang tidak terlalu jauh dari oli Federal dan banyaknya konsumen yang menggunakan produk oli TOP 1.

Tabel 1 : Perbandingan harga Oli Federal dan Oli Top 1

\begin{tabular}{ll}
\hline \multicolumn{1}{c}{ Oli Federal } & \multicolumn{1}{c}{ Oli TOP 1 } \\
\hline $\begin{array}{l}\text { FEDERAL SUPREME XX 20W/50 0,8 L SJ } \\
\text { Rp25,500 }\end{array}$ & TOP 1 MC 20W/50 0,8 L SH Rp21,500 \\
\hline $\begin{array}{l}\text { FEDERAL ULTRATECH 20W/50 0,8 L SF } \\
\text { Rp19,500 }\end{array}$ & $\begin{array}{l}\text { TOP 1 MC EVOLUTION 15W/50 0,8 L SL } \\
\text { Rp35,000 }\end{array}$ \\
\hline $\begin{array}{l}\text { FEDERAL ULTRATECH 20W/50 1 L SF } \\
\text { Rp23,500 }\end{array}$ & \begin{tabular}{l} 
TOP 1 HP 20W/50 1 L SL Rp28,500 \\
\hline
\end{tabular}
\end{tabular}

TOP 1 MC 20W/50 1 L SH Rp24,000

Sumber: http://privateers.wordpress.com/2007/05/23/daftar-harga-jual-oli/

Dikutip dari www.priyadi.net telah mengatakan bahwa "Oli Top-1 adalah salah satu oli yang paling populer di Indonesia, serta mengalahkan produk pesaingnya seperti Oli Castrol dan Oli Federal. Oli merk ini sering dipromosikan di berbagai media dengan pesan "Oli 
yang banyak dipakai oleh artis" atau "Oli nomor satu di Amerika". Bahkan merk ini adalah salah satu dari 100_Superbrands Indonesia".

\section{KAJIAN TEORI}

\section{Kualitas Produk}

Kualitas produk merupakan kemampuan produk di dalam menjalankan fungsinya dan kualitas produk dapat diukur melalui pendapat konsumen tentang kualitas itu sendiri, sehingga selera pribadi sangat mempengaruhi. Kualitas itu sendiri sering dianggap sebagai ukuran relatif kebaikan suatu produk atau jasa. Nilai subyektifitas dari seseorang menyebabkan adanya perbedaan dalam memberikan pengertian mengenai kualitas.

Menurut Kotler and Armstrong (2012:283) arti dari kualitas produk adalah kemampuan sebuah produk dalam memperagakan fungsinya, hal itu termasuk keseluruhan durabilitas, reliabilitas, ketepatan, kemudahan pengoperasian dan reparasi produk juga atribut produk lainnya.

Menurut Griffin dan Ebert (2006:434) kualitas produk didefinisikan sebagai menciptakan kesesuaian untuk menawarkan fitur penggunaan yang diinginkan konsumen.

Kotler (2010:361) menjelaskan bahwa terdapat 9 (sembilan) dimensi kualitas produk yang membedakan suatu produk dengan lainnya, yaitu :

1. Form (bentuk), artinya produk dapat dibedakan secara jelas dengan yang lainnya berdasarkan bentuk, ukuran, atau struktur fisik produk.
2. Features (ciri-ciri produk), merupakan karakteristik atau sifat yang menunjang fungsi-fungsi dasar suatu produk.

3. Performance quality (kualitas kinerja), menggambarkan kinerja atau tingkat kemampuan operasional suatu produk.

4. Conformance quality (kualitas ketepatan), menunjukkan sejauh mana rancangan dan kinerja suatu produk dapat memenuhi standar yang telah ditetapkan.

5. Durability (ketahanan), diartikan sebagai harapan hidup suatu produk atau berapa lama suatu produk dapat digunakan.

6. Reliability (keandalan), mengukur kemungkinan suatu produk tidak akan rusak dalam jangka waktu tertentu. Konsumen akan lebih menyukai membayar mahal untuk mendapat produk berkualitas tinggi daripada membayar mahal untuk reparasi produk.

7. Repairability

(kemudahan perbaikan), jika produk tersebut rusak, dapat dengan mudah untuk diperbaiki. Idealnya, produk dapat diperbaiki sendiri dengan mudah dan cepat oleh pengguna.

8. Style (gaya), menjelaskan penampilan produk dan perasaan konsumen mengenai produk tersebut.

9. Design (desain atau model), menunjukkan keseluruhan keistimewaan produk yang akan mempengaruhi penampilan dan fungsi produk dalam memenuhi keinginan konsumen. 


\section{Citra Merek}

Dengan semakin banyaknya produk dan jasa yang dapat dengan mudah ditiru oleh para pesaing, menyebabkan konsumen seringkali tidak dapat membeda-bedakan antara merek suatu produk dan jasa suatu perusahaan dengan merek suatu produk dan jasa pesaingnya. Untuk itu pemasar harus mengembangkan suatu citra merek yang khas dan dapat diterima oleh konsumen, sehingga konsumen dapat menentukan pilihan atas merek suatu produk atau jasa tertentu.

Definisi citra merek menurut Kotler (2003:51) Yaitu citra merek adalah kreasi yang diciptakan oleh program-program pemasaran yang memiliki link yang sangat menguntungkan, dan asosiasi yang unik yang tertanam dalam memori konsumen.

Menurut Richard E. Stanley alih bahasa Ratna Junita (2004:19) citra merek adalah kesan tertanam dalam benak konsumen mengenai suatu barang tertentu yang dapat diperoleh dari berbagai kreativitas yang dilakukan oleh produsen melalui media-media promosi.

Brand Image dapat dijelaskan dalam tiga bagian yaitu atribut, manfaat dan evaluasi sikap konsumen terhadap merek tersebut (et al, A.Shimp, 2003:10).

1. Atribut adalah ciri-ciri khas atau berbagai aspek dari merek yang diiklankan. Atribut juga dibagi menjadi dua bagian yaitu:

a. Hal-hal yang tidak berhubungan dengan produk (contoh: harga, kemasan, pemakai dan citra penggunaan).

b. Hal-hal yang berhubungan dengan produk (contoh: warna ukuran dan desain).

2. Bagian kedua dari brand image adalah manfaat, manfaat dibagi dalam tiga bagian, yaitu:

a. Fungsional: manfaat yang berusaha untuk menyediakan solusi bagi masalah-masalah konsumsi atau potensi permasalahan yang dapat dihadapi oleh konsumen, dengan mengkomunikasikan bahwa suatu merek memiliki manfaat spesifik yang dapat memecahkan masalahmasalah tersebut.

b. Simbolis: berusaha mengarahkan kepada keinginan konsumen dalam upaya memperbaiki diri, dihargai sebagai anggota dari suatu kelompok, afiliasi dan rasa memiliki.

c. Pengalaman: konsumen merupakan representasi dari keinginan mereka akan produk yang dapat memberikan rasa senang, keanekaragaman, dan stimulasi kognitif.

3. Sedangkan bagian ketiga dari brand image adalah evaluasi sikap diri yaitu nilai atau kepentingan subyektif dimana pelanggan menambahkannya pada hasil konsumsi.

\section{Loyalitas Konsumen}

Loyalitas konsumen adalah suatu perilaku konsumen membeli dari 
produsen atau penjual yang sama dalam jangka waktu yang cukup lama. Konsumen yang sudah loyal pada suatu produk akan berulangulang membeli produk dari perusahaan tersebut. Menurut Oliver dalam Kotler dan Keller (2006:135), loyalitas konsumen didefinisikan sebagai sebuah komitmen yang dipegang teguh untuk membeli kembali atau menggunakan produk atau opsi layanan di masa mendatang meskipun pengaruh situasi dan upaya pemasaran memiliki potensi untuk menyebabkan terjadinya perubahan perilaku.

Selain itu, Kartajaya (2006 : 87) menyatakan bahwa Loyalitas konsumen adalah bagaimana perusahaan memiliki konsumen yang antusias, baik antusias untuk memakai produk dan servis perusahaan, antusias untuk selalu menjadi yang terdepan untuk mengetahui produk atau servis terbaru perusahaan, antusias untuk menjadi penasihat bagi perusahaan maupun antusias untuk memberitakan produk atau servis perusahaan kepada orang lain.

Menurut Griffin (2005:31), indikator konsumen yang loyal terhadap suatu produk atau jasa, yaitu:

1. Melakukan pembelian secara teratur.

2. Pembelian antar lini produk atau jasa.

3. Mereferensikan ke orang lain.

4. Menunjukkan kekebalan dari tarikan persaingan (tidak mudah terpengaruh oleh tarikan persaingan produk sejenis lainnya).

Dari semua penjelasan di atas dapat digambarkan model kerangka pemikiran berikut:

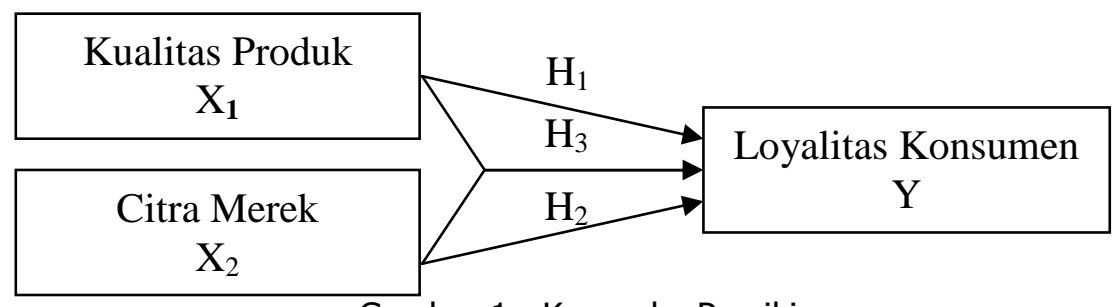

Gambar 1 : Kerangka Pemikiran

Sumber : Data Diolah Peneliti

Hipotesis merupakan jawaban sementara yang masih harus dibuktikan kebenarannya melalui penelitian. Hipotesis dalam penelitian ini adalah:

$\mathrm{H} 1$ : Kualitas produk berpengaruh signifikan terhadap loyalitas konsumen.
H2: Citra merek berpengaruh signifikan terhadap loyalitas konsumen.

H3: Kualitas produk dan citra merek berpengaruh signifikan terhadap loyalitas konsumen. 


\section{METODE PENELITIAN}

Metode penelitian

yang

digunakan dalam penelitian ini adalah metode survei. Menurut Malhotra (2005:95), desain penelitian adalah bingkai kerja atau cetak biru untuk melaksanakan proyek riset pemasaran. Sementara itu, Mohammad Nazir (2003:84) mendefinisikan desain penelitian sebagai semua proses yang diperlukan dalam perencanaan dan pelaksanaan penelitian.

Terdapat dua desain penelitian yang digunakan dalam penelitian ini, yaitu deskriptif dan kausal. Desain deskriptif adalah salah satu jenis riset konklusif yang mempunyai tujuan utama menguraikan sesuatu yang biasanya karakteristik atau fungsi pasar (Malhotra, 2005:93). Sedangkan riset desain atau riset kausal adalah suatu jenis riset yang digunakan untuk membuktikan hubungan sebab akibat (Malhotra, 2005:100).

Desain atau riset deskriptif bertujuan untuk menguraikan tentang karakteristik responden, pengalaman responden dan tanggapan responden terhadap variabel penelitian, sedangkan desain kausal bertujuan untuk mengetahui pengaruh kualitas produk dan citra merek sebagai variabel $X_{1}$ dan $X_{2}$ terhadap loyalitas konsumen sebagai variabel $Y$. Dalam penelitian ini peneliti menggunakan data primer. Yaitu pengumpulan data melalui survei.

Instrumen pengumpulan data dalam penelitian ini adalah kuesioner. Kuesioner yang disebarkan berupa seperangkat pertanyaan dengan bentuk tertutup, dimana pertanyaan tersebut dibuat sedemikian rupa sehingga responden dibatasi dalam memberikan jawabannya. Kuesioner yang digunakan adalah kuesioner dimana setiap item soal disediakan 5 (lima) pilihan jawaban. Dalam penelitian ini jawaban yang diberikan oleh responden kemudian diberi skor dengan mengacu pada skala Likert. Selain itu peneliti menggunakan data sekunder. Data ini didapatkan dari studi kepustakaan. Penyebaran kuesioner dilakukan pada saat konsumen datang ke bengkel AHASS. Sedangkan tempat penyebaran kuesioner yaitu pada bengkel AHASS di Jalan Dewi Sartika No. 297, Jakarta Timur.

Populasi berdasarkan pendapat Malhotra (2004:314) adalah gabungan seluruh elemen yang memiliki karakteristik serupa, yang mencakup semesta untuk kepentingan masalah riset pemaaran. Populasi dalam penelitian ini adalah seluruh konsumen produk oli Federal pada bengkel resmi Ahass 2657 Dewi Sartika.

Malhotra (2010:371) sampel adalah sub kelompok populasi yang terpilih untuk berpartisipasi dalam studi. Penggunaan sampel bertujuan untuk mempermudah penelitian, yaitu dengan mengambil sebagian objek populasi yang mempunyai peluang sama untuk menjadi sampel sehingga sampel tersebut dapat mewakili populasi yang diteliti. Pengambilan sampel dalam penelitian ini menggunakan metode convenience sampling. Menurut Siagian dan Sugiarto (2000:120) convenience 
sampling merupakan pengambilan sampling berdasarkan ketersediaan elemen dan kemudahan untuk mendapatkannya.

Populasi konsumen pada bengkel AHASS berjumlah 418. Menurut Umar (1998:78) jika jumlah populasi diketahui, maka jumlah sampel dapat ditentukan dengan mengunakan rumus Slovin sebagai berikut:

$\mathrm{n}=\frac{\mathrm{N}}{1+\mathrm{N} \mathrm{e}^{2}}$

Dimana: $\mathrm{n}=$ Ukuran sample

$\mathrm{N}=$ Ukuran populasi

e $=$ Persentase

kelonggaran ketidaktelitian karena kesalahan pengambilan sampel yang masih dapat ditoleril atau diinginkan. ( margin of error $=5 \%$ )

Sehingga jumlah sampel yang penulis teliti untuk populasi tersebut adalah 204 responden. Dalam menganalisis data metode yang digunakan adalah rumus analisis regresi berganda. Untuk pengolahan data dalam penelitian ini, peneliti mengunakan program aplikasi pengolahan data SPSS.

\section{HASIL DAN PEMBAHASAN}

Setelah dilakukan pengujian kepada 30 responden yang merupakan konsumen oli Federal, variabel kualita produk $\left(\mathrm{X}_{1}\right)$ menunjukkan bahwa 11 item dinyatakan valid, variabel citra merek $\left(X_{2}\right)$ menujukkan bahwa 7 item yang dinyatakan valid, dan variabel loyalitas konsumen ( $Y$ ) menunjukkan bahwa 6 item yang dinyatakan valid.

Dari pengujian reliabilitas kuesioner dengan mengunakan SPSS 17.0, dapat dilihat dari nilai Cronbach Alpha dari masing-masing variabel.

Tabel 2 : Hasil Uji Reliabilitas

\begin{tabular}{ccc}
\hline Variabel & Alpha & Keterangan \\
\hline $\mathrm{X} 1$ & 0.800 & Reliabel \\
\hline $\mathrm{X} 2$ & 0.738 & Reliabel \\
\hline $\mathrm{Y}$ & 0.830 & Reliabel
\end{tabular}

Sumber : Perhitungan SPSS

Berdasarkan hasil uji reliabilitas nilai korelasi Alpha Cronbach variabel kualitas produk adalah $\mathrm{a}=0.800$, citra merek $a=0.738$, dan loyalitas konsumen $a=0.830$. Menurut Uma Sekaran (2003:311), skala pengukuran yang reliabel sebaiknya memiliki Alpha Cronbach berkisar antara 0,70 sampai 0,80 . Jadi, instrumen dari ketiga variabel diatas dinyatakan valid karena nilai Alpha Cronbach melebihi 0,70. 
Tabel 3 : Hasil Uji Normalitas dengan Kolomogrov-Smirnov Tests of Normality

\begin{tabular}{lcccccc}
\hline & \multicolumn{3}{c}{ Kolmogorov-Smirnov(a) } & \multicolumn{4}{c}{ Shapiro-Wilk } \\
\cline { 2 - 8 } & Statistic & df & Sig. & Statistic & df & Sig. \\
\hline Kualitas Produk & .061 & 204 & .062 & .972 & 204 & .000 \\
(X1) & .059 & 204 & .081 & .983 & 204 & .015 \\
Citra Merek (X2) & .061 & 204 & .066 & .986 & 204 & .038 \\
Loyalitas & .061 & & & & & \\
Konsumen (Y) & L Lilliefors Significance Correction & & & & & \\
$\quad$ Sumber : Perhitungan SPSS & & & & &
\end{tabular}

Hasil uji normalitas menunjukkan bahwa nilai signifikansi untuk variabel kualitas produk sebesar 0.062 , citra merek, sebesar 0.081, dan loyalitas konsumen sebesar 0.066 . Jadi variabel kualitas produk, citra merek, dan loyalitas konsumen populasinya berdistribusi normal karena nilai signifikansi untuk seluruh variabel lebih besar dari $a=0.05$.

Tabel 4 : Hasil Uji Multikolinearitas Coefficients (a)

\begin{tabular}{llrrrrr}
\hline \multirow{2}{*}{ Model } & & \multicolumn{3}{c}{ Correlations } & \multicolumn{3}{c}{ Collinearity } \\
& & & Statistics \\
\cline { 2 - 7 } & & Zero- & & & & \\
& & order & Partial & Part & Tolerance & VIF \\
\hline \multirow{2}{*}{1} & Kualitas Produk (X1) & .641 & .583 & .486 & .892 & 1.121 \\
& Citra Merek (X2) & .553 & .472 & .362 & .892 & 1.121 \\
\cline { 2 - 8 }
\end{tabular}

a Dependent Variable: Loyalitas Konsumen $(\mathrm{Y})$

Sumber : Perhitungan SPSS

Dari hasil diatas dapat diketahui nilai variance inflation factor (VIF) kedua variabel yaitu kualitas produk dan citra merek adalah 1.121 lebih kecil dari 10, sehingga dapat disimpulkan bahwa antar variabel independen tidak terjadi persoalan multikolinearitas. 
Tabel 5 : Hasil Uji Heteroskedastisitas

Coefficients(a)

\begin{tabular}{|c|c|c|c|c|c|c|}
\hline \multirow[b]{2}{*}{ Model } & & \multicolumn{2}{|c|}{$\begin{array}{l}\text { Unstandardized } \\
\text { Coefficients }\end{array}$} & \multicolumn{2}{|c|}{$\begin{array}{l}\text { Standardized } \\
\text { Coefficients }\end{array}$} & \multirow[b]{2}{*}{ Sig. } \\
\hline & & B & $\begin{array}{l}\text { Std. } \\
\text { Error }\end{array}$ & Beta & $\mathrm{t}$ & \\
\hline 1 & (Constant) & 6.827 & 3.201 & & 2.133 & .034 \\
\hline & $\ln X 1$ & -1.138 & .804 & -.105 & -1.416 & .158 \\
\hline & $\ln \times 2$ & -.719 & .813 & -.066 & -884 & 378 \\
\hline
\end{tabular}

a Dependent Variable: Inei2

Sumber : Perhitungan SPSS

Dari uji heterokedastisitas, nilai t hitung $X 1$ sebesar -1.416 dan nilai probabilitas sebesar 0.158 lebih besar dari $\mathrm{a}=0.05$ maka dapat dinyatakan bahwa tidak ada gejala heteroskedastisitas pada data variabel
X1. Demikian juga variabel X2 yang memiliki nilai t hitung -0.884 dan nilai probabilitas 0.378 lebih besar dari $a=$ 0.05 , maka dapat dinyatakan bahwa tidak ada gejala heteroskedastisitas pada data variabel X2.

Tabel 6 : Analisis determinasi Kualitas Produk dan Citra Merek Terhadap Loyalitas Konsumen

Model Summary

\begin{tabular}{llrrr}
\hline Model & $\mathrm{R}$ & R Square & $\begin{array}{c}\text { Adjusted R } \\
\text { Square }\end{array}$ & $\begin{array}{c}\text { Std. Error of } \\
\text { the Estimate }\end{array}$ \\
\hline 1 & $.736(\mathrm{a})$ & .542 & .537 & 2.374 \\
\hline a Predictors: (Constant), Citra Merek (X2), Kualitas Produk (X1) \\
Sumber : Perhitungan SPSS
\end{tabular}

Dari tabel di atas, $R^{2}$ ( $R$ square) sebesar 0.542 atau $54.2 \%$. Angka ini menunjukkan bahwa $54.2 \%$ variasi nilai dari variabel loyalitas konsumen (Y) dijelaskan oleh variabel kualitas produk (X1) dan variabel citra merek (X2). Sedangkan sisanya $45.8 \%$ dijelaskan oleh variabel lain yang tidak dibahas dalam penelitian ini.

\section{Deskripsi Variabel Kualitas Produk}

Variabel kualitas produk pada dimensi pertama yaitu bentuk, secara umum responden memberikan respon yang positif, yaitu dengan jawaban setuju sebesar $49.8 \%$, dan sebesar $15.0 \%$ responden menjawab sangat setuju. Maka dapat disimpulkan bahwa konsumen menyukai bentuk dari produk oli Federal tersebut. Namun sebagian konsumen yang 
menjawab kurang setuju sebanyak $21.6 \%$, tidak setuju $12.7 \%$. Maka perusahaan bisa memberikan inovasi untuk bentuk kemasan dan variasi oli sesuai dengan kebutuhan konsumen.

Selanjutnya dimensi kedua adalah ciri-ciri produk (feature). Secara umum responden memberikan respon yang positif, yaitu dengan sebanyak $48.0 \%$ responden menjawab dengan jawaban setuju, $17.6 \%$ responden menjawab dengan sangat setuju, dan sebanyak $11.8 \%$ responden menjawab dengan jawaban tidak setuju. Maka dapat disimpulkan bahwa ciri-ciri dari produk oli Federal sudah banyak diketahui oleh para konsumennya.

Selanjutnya dimensi ketiga adalah kualitas kinerja (performance quality). Kualitas kinerja dari oli Federal dianggap baik oleh para konsumen. Hal ini dapat dibuktikan dengan jawaban responden sebanyak $43.3 \%$ menjawab setuju, $16.5 \%$ menjawab sangat setuju, $25.8 \%$ menjawab kurang setuju atau raguragu. Dapat disimpulkan sebagain konsumen telah merasakan manfaat dari kinerja oli Federal.

Kualitas ketepatan (conformance quality) merupakan dimensi yang keempat. Secara umum responden memberikan respon yang positif dengan menjawab setuju sebanyak $43.6 \%$. Sebanyak $17.9 \%$ responden menjawab sangat setuju dan jawaban kurang setuju di jawab responden dengan persentase $20.1 \%$. Maka dapat disimpulkan bahwa konsumen yakin terhadap kualitas ketepatan yang diberikan oleh produk oli Federal.
Dimensi kelima adalah ketahanan (durability). Pada dimensi ini sebanyak $11.3 \%$ responden menjawab sangat setuju dan $40.2 \%$ responden menjawab setuju. Hal ini dapat disimpulkan bahwa konsumen beranggapan bahwa pemakaian oli Federal mempunyai ketahanan yang lama melebihi produk oli yang lainnya.

Desain (design) merupakan dimensi terakhir dari kualitas produk. $46.3 \%$ responden menjawab setuju dan $16.2 \%$ responden menjawab setuju. Dapat disimpulkan bahwa desain yang terdapat pada produk oli Federal disukai oleh sebagian konsumennya.

\section{Deskripsi Variabel Citra Merek}

Pada dimensi atribut, terdapat dua penyataan seputar atribut dari produk oli Federal. Secara umum responden memberikan respon positif yaitu sebanyak $49.8 \%$ responden menjawab setuju terhadap atribut dari produk oli Federal, sebanyak $15.4 \%$ responden menjawab setuju, dan $21.8 \%$ responden menjawab kurang setuju atau ragu-ragu. Maka dapat disimpulkan bahwa secara umum atribut dari produk oli Federal dinilai baik oleh konsumennya.

Manfaat adalah dimensi kedua dari citra merek. Sebanyak 12.9\% responden menjawab sangat setuju, $42.6 \%$ responden menjawab setuju, dan sebanyak $15.4 \%$ responden menjawab tidak setuju. Dengan demikian dapat disimpulkan bahwa sebagian para konsumen sudah dapat menerima manfaat dari pemakaian produk oli Federal walaupun ada 
sebagian kecil konsumen yang belum menerima manfaat dari pemakaian oli Federal.

Dimensi terakhir adalah evaluasi keseluruhan (sikap). Secara umum responden memberikan respon yang positif, yaitu sebesar $42.6 \%$ responden menjawab setuju. Lalu sebanyak $15.7 \%$ menjawab tidak setuju. Maka dapat disimpulkan bahwa mayoritas responden memiliki sikap positif terhadap produk oli Federal.

\section{Deskripsi Variabel Loyalitas Konsumen}

Dimensi pertama yaitu melakukan pembelian secara teratur. Secara umum responden memberikan respon yang positif sebesar $54.9 \%$ responden menjawab setuju, 19.6\% responden menjawab ragu-ragu atau kurang setuju, dan $16.7 \%$ responden menjawab sangat setuju. Maka, dapat disimpulkan bahwa sebagian besar konsumen produk oli Federal selalu melakukan pembelian produk oli Federal secara teratur.

Dimensi kedua adalah mereferensikan kepada orang lain. Berdasarkan data yang diperoleh, responden menjawab setuju sebanyak $49.3 \%$ dan yang menjawab sangat setuju sebanyak $15.7 \%$. Jadi dapat disimpulkan bahwa sebagian besar konsumen umumnya mereferensikan produk oli Federal untuk digunakan kepada kerabatnya.

Menunjukkan kekebalan dari tarikan persaingan produk sejenis lainnya. merupakan dimensi yang terakhir. Secara umum responden memberikan respon yang positif. Hal ini dapat dilihat dari sebanyak $45.8 \%$ menjawab setuju dan sebanyak $11.0 \%$ responden menjawab sangat setuju. Dapat dilihat bahwa sebagian konsumen tidak mudah tertarik pada produk pesaingnya.

Tabel 7 : Hasil Uji t

Coefficients(a)

\begin{tabular}{|c|c|c|c|c|c|c|}
\hline \multirow[t]{2}{*}{ Model } & & \multicolumn{2}{|c|}{$\begin{array}{c}\text { Unstandardized } \\
\text { Coefficients }\end{array}$} & $\begin{array}{c}\text { Standardize } \\
\mathrm{d} \\
\text { Coefficients }\end{array}$ & $\mathrm{t}$ & Sig. \\
\hline & & B & $\begin{array}{l}\text { Std. } \\
\text { Error }\end{array}$ & Beta & & \\
\hline \multirow[t]{3}{*}{1} & (Constant) & 4.736 & 1.141 & & 4.152 & .000 \\
\hline & $\begin{array}{l}\text { Kualitas Produk } \\
\text { (X1) }\end{array}$ & .249 & .024 & .515 & 10.182 & .000 \\
\hline & $\begin{array}{l}\text { Citra Merek } \\
(\mathrm{X} 2)\end{array}$ & .301 & .040 & .384 & 7.591 & .000 \\
\hline
\end{tabular}

a Dependent Variable: Loyalitas Konsumen ( $Y$ )

Sumber : Perhitungan SPSS

Hasil analisis uji $t$ adalah sebagai berikut:
1. Nilai $t$ hitung pada variabel Kualitas Produk (X1) adalah 
sebesar 10.182 dengan tingkat signifikansi 0,000 . Karena 0,000 $<\mathrm{a}=0.05$ maka Ho ditolak dan Ha diterima. Maka dapat disimpulkan bahwa variabel kualitas produk mempunyai pengaruh yang signifikan terhadap variabel loyalitas konsumen.
2. Nilai $t$ hitung pada variabel Citra Merek (X2) adalah sebesar 7.591 dengan tingkat signifikansi 0,000 . Karena $0,000<a=0,05$ maka Ho ditolak dan Ha diterima. Maka dapat disimpulkan bahwa citra merek mempunyai pengaruh yang signifikan terhadap loyalitas konsumen.

Tabel 8 : Uji f variabel Kualitas Produk dan Citra Merek Terhadap Loyalitas Konsumen

ANOVA(b)

\begin{tabular}{lllrrrl}
\hline Model & & $\begin{array}{l}\text { Sum of } \\
\text { Squares }\end{array}$ & \multicolumn{1}{c}{ df } & \multicolumn{1}{c}{ Sean } & \\
\hline 1 & Reguare & \multicolumn{1}{c}{$\mathrm{F}$} & Sig. \\
& on & 1339.097 & 2 & 669.549 & 118.810 & $.000(\mathrm{a})$ \\
& Residual & 1132.726 & 201 & 5.635 & & \\
& Total & 2471.824 & 203 & & & \\
\hline
\end{tabular}

a Predictors: (Constant), Citra Merek (X2), Kualitas Produk (X1)

b Dependent Variable: Loyalitas Konsumen $(\mathrm{Y})$

Sumber : Perhitungan SPSS

Pada penelitian ini menggunakan nilai signifikansi $a=0.05$. Nilai $f$ hitung adalah 118.810 sedangkan signifikansi diperoleh 0,000 . Karena signifikan $0,000<a=0,05$, maka artinya terdapat pengaruh secara simultan antara variabel Kualitas Produk (X1) dan Citra Merek (X2) Terhadap Loyalitas Konsumen (Y).

\section{KESIMPULAN DAN SARAN Kesimpulan}

Berdasarkan penelitian yang telah dilakukan, maka diperoleh berupa deskriptif dan kausal. Berikut adalah beberapa kesimpulan:

1. Berdasarkan hasil penelitian yang dilakukan, dapat disimpulkan bahwa deskripsi dari kualitas produk adalah oli Federal adalah oli buatan Jepang yang di produksi di Indonesia. Kualitas produk oli Federal sudah cukup baik dalam hal kualitas kinerja oli tersebut, kualitas ketepatan, dan desain dari produk. Deskripsi citra merek pada oli Federal adalah bahwa oli Federal merupakan oli khusus buatan untuk motor Honda, tetapi seluruh motor buatan Jepang juga bisa menggunakan produk ini. Lalu dapat dilihat dari manfaat yang diberikan dari produk oli Federal misalnya tidak membuat mesin menjadi mudah panas dan dapat menurunkan tingkat keausan pada mesin. Citra yang baik pula 
dapat dilihat pada reputasi perusahaan yang baik dalam pembuatan oli. Deskripsi loyalitas konsumen pada oli Federal adalah konsumen telah melakukan pergantian oli lebih dari empat kali. Kesetiaan konsumen dapat dilihat dari pemakaian oli Federal yang berulang-ulang. Selain itu dapat dilihat dari kekebalan konsumen dari tarikan pesaing produk sejenis lainnya. Tetapi ada sebagian konsumen belum bisa melakukan penolakan terhadap produk pesaingnya.

2. Nilai $t$ hitung pada variabel Kualitas Produk (X1) adalah sebesar 10.182 dengan tingkat signifikansi 0,000. Karena 0,000 $<\mathrm{a}=0.05$ maka Ho ditolak dan $\mathrm{Ha}$ diterima. Maka dapat disimpulkan bahwa variabel kualitas produk mempunyai pengaruh yang signifikan terhadap variabel loyalitas konsumen. Kualitas produk yang baik pada oli Federal akan menimbulkan suatu kesetiaan dalam pemakaian produk pada konsumen.

3. Nilai t hitung pada variabel Citra Merek (X2) adalah sebesar 7.591 dengan tingkat signifikansi 0,000 . Karena $0,000<a=0,05$ maka Ho ditolak dan Ha diterima. Maka dapat disimpulkan bahwa citra merek mempunyai pengaruh yang signifikan terhadap loyalitas konsumen. Citra merek yang melekat baik akan membuat konsumen tidak ragu lagi untuk menggunakan suatu produk, dan jika puas akan menimbulkan kesetiaan dalam menggunakan produk tersebut.

4. Berdasarkan hasil penelitian yang dilakukan, dapat disimpulkan bahwa hasil analisis dari variabel kualitas produk $\left(X_{1}\right)$ dan citra merek $\left(X_{2}\right)$ secara simultan mempengaruhi variabel loyalitas konsumen ( $\mathrm{Y}$ ). Nilai koefisien determinasi sebesar $54.2 \%$ menunjukkan variasi nilai dari variabel loyalitas konsumen ( $Y$ ) dijelaskan oleh variabel kualitas produk (X1) dan variabel citra merek (X2). Sedangkan sisanya $45.8 \%$ dijelaskan oleh variabel lain yang tidak dibahas dalam penelitian ini.

\section{Saran}

Saran bagi perusahaan :

1. Terkait dengan banyaknya konsumen yang tidak mengetahui bahwa oli Federal bisa digunakan untuk semua motor buatan teknologi Jepang, maka sebaiknya perusahaan memberitahukan dengan cara berpromosi terkait hal tersebut. Bisa promosi melalui media cetak dan media elektronik.

2. Perusahaan sebaiknya memberikan suatu layanan agar para konsumen lebih mengetahui dan bisa berbagi informasi tentang oli Federal antara satu konsumen dengan konsumen lainnya. Misalnya bisa dengan membuat komunitas konsumen pengguna oli Federal pada website dan bisa juga membuat sebuah blog. 
3. Perusahaan sebaiknya memberikan logo bertuliskan standar yang tetap ditetapkan. Misalnya dengan logo Standar Nasional Indonesi (SNI). Agar konsumen lebih percaya untuk dapat menggunakan produk oli Federal.

4. Terkait durasi pemakaian oli, sebaiknya perusahaan memberikan batasan kilometer pada kemasan oli agar konsumen bisa mengetahui batas penggunaan oli.

5. Pihak perusahaan sebaiknya memberikan produk yang lebih tahan lama dari segi pemakaian. Misalnya memberikan pergantian oli lebih dari $3000 \mathrm{~km}$.

6. Pihak perusahaan sebaiknya bisa memberikan kemasan produk yang terbaik. Misalnya dengan kemasan yang ringan, dari bahan yang berkualitas, dan mudah di bawa tanpa menggunakan plastik.

7. Perusahaan sebaiknya menginformasikan bahwa sudah lama berkecimpung dalam pembuatan oli, mempunyai pabrik sendiri, dan mempunyai sistem distribusi yang baik.

\section{DAFTAR PUSTAKA}

Griffin, Jill. (2005). Customer Loyalty. Menumbuhkan dan Mempertahankan Kesetiaan Pelanggan. Alih Bahasa: Dwi Kartini Yahya. Jakarta: Erlangga

Griffin, Ricky W., and Ronald J. Ebert. (2006). Business. New Jersey: Pearson

Education Inc.

Kotler, Philip., \& Armstrong, G (2012). Principle of marketing. Upper Saddle River, N.J: Pearson Prentice Hall.

Kotler, Philip. Marketing Management. (2003). 11th edition/International Edition. Prentice Hall: New Jersey

Kotler, Philip, \& Keller, Kevin Lane. (2006). Marketing management (12thed.). NewJersey : Prentice Hall, Inc.

Kotler, Philip dan Kevin Lane Keller. 2010. Manajemen Pemasaran. Edisi 13,Jilid 1. Jakarta : Glora Aksara Pratama

Shimp, Terence A (2003). Periklanan Promosi, Jilid 1. Jakarta: Erlangga. 